\title{
FACTORS ASSOCIATED WITH HYGIENIC QUALITY OF BULK TANK MILK PRODUCED IN CENTRAL POLAND
}

\author{
Jarosław Pytlewski ${ }^{1}$, Ireneusz Antkowiak ${ }^{1}$, Maciej Adamski ${ }^{2}$, \\ Josef Kučera ${ }^{3}$, Ryszard Skrzypek ${ }^{1}$ \\ ${ }^{1}$ Department of Cattle Breeding and Milk Production, Poznań University of Life Sciences, \\ Wołyńska 33, 60-637 Poznań, Poland \\ ${ }^{2}$ Institute of Animal Breeding, Department of Cattle Breeding and Milk Production, \\ Wrocław University of Environmental and Life Sciences, Chełmońskiego 38 C, \\ 51-630 Wrocław, Poland \\ ${ }^{3}$ Czech Fleckvieh Breeders Association, U Topíren 2, 17041 Praha 7, Czech Republic \\ Corresponding author: skrzypek@jay.up.poznan.pl
}

\begin{abstract}
The aim of this study was a complex analysis of organizational and technological factors affecting somatic cell count (SCC) and total microorganism count (SPC) in bulk tank milk produced in the area of Lódź Voivodeship. The study was conducted on the basis of a questionnaire completed directly in $\mathbf{2 0 5}$ family farms, maintaining Polish Black-and-White Holstein-Friesian cows. The data were analysed statistically using multifactor analysis of variance. The following factors decreased SCC in milk: application of mechanical ventilation in the cowshed; disinfection of stalls for cows; frequent inspection of milking equipment efficiency by a specialized service (twice vs. once a year); application of manual pre-milking udder massage; dry period of a standard length of 6-8 weeks (vs. 2-5 weeks); application of concentrates in amounts of at least $3 \mathrm{~kg} / \mathrm{day} / \mathrm{cow}$; application of meadow hay and straw or hay only among roughages in cow feeding (vs. straw only); addition of vitamin $\mathrm{E}$ and $\mathrm{Cu}$ to feeding ration for cows and individual housing of replacement heifers between 1-3 months of age (vs. group system). In turn, the following factors decreased SPC: participation of milkers in specialist trainings; cleaning of teats before milking using wet towel or washing with water containing a disinfectant; "dry" storage of milking equipment between milkings; culling of cows due to mastitis; application of vitamin $A$ and $\mathrm{Zn}$; no use of milk from mastitic cows in calf feeding; and individual housing of replacement heifers during the first month of life.
\end{abstract}

Key words: cows, herd management, bulk tank milk, SCC, SPC

The most important criteria of an assessment of hygienic quality of bulk tank milk are somatic cell count (SCC) and total microorganism count (SPC; Standard Plate Count). SCC reflects the health status of an udder, because the main factor causing an elevated level are inflammations of this gland resulting from infections, 
known as mastitis (Malinowski, 2001). According to the current standards, the extra class milk in Poland and other EU countries may include up to 400,000 somatic cells in $1 \mathrm{ml}$ of milk. However, the accepted value characteristic of the full health status is 100,000 in $1 \mathrm{ml}$, because losses occur starting just from this limit, and they are manifested in decreased production of milk with lowered fat and crude protein contents, and in deteriorated processing and consumption quality of milk. What is more, the length of productive life of cows is shortened, and in extreme cases mastitis may be a significant reason for their premature culling (Rodrigues et al., 2005; Pytlewski et al., 2010; Dufour et al., 2011). The number of somatic cells in milk is influenced by genetic (Skrzypek and Szukalski, 2006; Ptak et al., 2011) and numerous environmental factors (Barkema et al., 1998; Skrzypek, 2002; Kamieniecki et al., 2004; Wroński et al., 2008; O’Rourke, 2009; Dufour et al., 2011). Somatic cells do not proliferate in milk and thus are a very good indirect diagnostic tool in an assessment of udder health status.

Microorganisms, in turn, potentially proliferate in milk all the time after its synthesis, therefore its microbiological quality at the moment of collection by the dairy plant depends directly on health status of the udder, and also on milking hygiene and milk handling after milking (Borkowska et al., 2001; Gardzina et al., 2002; Kamieniecki et al., 2004; Wroński et al., 2008; Elmoslemany et al., 2010). For that reason, in spite of the numerous common conditions of SCC and SPC, the level of both parameters is determined in milk while assessing hygienic quality of bulk tank milk. According to Polish and EU standards, the content of microorganisms in extra class milk cannot exceed 100,000 in $1 \mathrm{ml}$ of milk.

Because milk production in Poland is the most important domain of agricultural production, and a regular supply of milk with SCC and SPC below threshold limits for extra class is a key condition of production profitability, a number of studies concerning factors determining the levels of both parameters have been conducted over the last ten years in western, northern, north-eastern and southern Poland (Borkowska et al., 2001; Gardzina et al., 2002; Skrzypek, 2002; Kamieniecki et al., 2004; Skrzypek et al., 2004; Wroński et al., 2008).

The aim of this study was a complex analysis of organizational and technological factors related to SCC and SPC in bulk tank milk produced by cows maintained in central Poland.

\section{Material and methods}

The research was conducted on 3423 Polish Black-and-White Holstein-Friesian cows kept at 205 family farms of Łódź Voivodeship. Milk was delivered to two dairy plants located in various parts of the region. The study was begun with a questionnaire conducted directly with farm owners at the beginning of 2008 (January-February). The questionnaire included 58 questions divided into the following groups: general factors, housing of cows, access of cows to yards and pastures, handling of cows during milking, prevention of udder and teat infections, handling of milk 
and milking equipment after milking, treatment and culling of cows suffering from mastitis, dry period management, feeding of cows and rearing of reproductive heifers starting from the day of birth. Next, using the database of both dairy plants, the information concerning SCC and SPC for the whole year 2007 was collected. The laboratory analyses of SCC were performed once or twice a month depending on the plant, and SPC analyses were performed twice a month.

For the statistical analysis, monthly weighted averages were calculated for both parameters, i.e. SCC and SPC, taking into account size of milk supply on the day of analysis, and the values obtained were transformed using natural logarithm. Next, the data was analysed using SAS ${ }^{\circledR}$ package (SAS 1996). Descriptive statistics (arithmetic means, standard deviations, observation range) were calculated in an initial phase for the size of the herd and SCC and SPC. Further, the coefficient of determination between SCC and SPC was estimated. The main calculations were made using multifactor analysis of variance according to GLM procedure. The analyses included these constant organizational and technological factors which on the farms analysed were noted at least in 2 variants, and the given variant included at least 7 herds. In addition to these factors, the model contained the constant effect of month (repeated variable) and random residual effect. The analysis of variance was performed so that elements of the highest probability of null hypothesis were gradually eliminated from the model while leaving only those which were significant at $\mathrm{P} \leq 0.01$ or $\mathrm{P} \leq 0.05$. The results of analysis of variance are presented as the exponentially transformed least squares means for $\log \mathrm{SCC}$ and $\log \mathrm{SPC}$.

\section{Results}

Table 1 presents descriptive statistics for the analysed farms. Means for the number of cows in the herd, amount of milk sold per cow, SCC and SPC were 16.7 head, 16.1 1/day, and 190,000 and 32,000 in $1 \mathrm{ml}$ of milk, respectively. The estimated coefficient of determination between both parameters of hygienic quality of milk was $0.05(\mathrm{P} \leq 0.01)$. The size of the herd and month had no significant relationship with SCC and SPC.

Table 1. Descriptive statistics for the investigated farms $(\mathrm{N}=205)$

\begin{tabular}{l|c|c|c|c}
\hline \multicolumn{1}{c|}{ Trait } & $\overline{\mathrm{x}}$ & SD & Minimum & Maximum \\
\hline Number of cows per farm & 16.7 & 6.6 & 6 & 45 \\
Average amount of milk sold per cow per day, 1 & 16.1 & 4.5 & 10.0 & 27.8 \\
Somatic cell count $(\times 1000 / \mathrm{ml}$ of milk) & 190 & 94 & 30 & 360 \\
Standard plate count $(\times 1000 / \mathrm{ml}$ of milk) & 32 & 12 & 10 & 68 \\
\hline
\end{tabular}

Table 2 contains the results of statistical analysis of factors significantly associated with SCC. The application of mechanical ventilation and disinfection of stalls for cows conducted at least once a year decreased the level of this parameter. Analysis of the procedures connected with milking and milking equipment showed that 
the pre-milking manual udder massage and milking equipment inspection conducted twice a year (vs. once a year) by specialized service had a decreasing influence on SCC. The application of a 6- to 8-week (vs. 2- to 5-week) dry period in cows was favourably connected with SCC. The following factors associated with cow feeding demonstrated a decreasing influence on SCC: application of concentrates in amounts above $3 \mathrm{~kg}$ /day per head, concurrent application of meadow hay and straw (vs. single application of these fodders, especially straw), and also supplementation with vitamin $\mathrm{E}$ and $\mathrm{Cu}$. Among the factors characterizing the growth of replacement heifers, a beneficial relationship with SCC was noted in the case of individual housing system between 1 and 3 months of age (vs. group system).

Table 2. Factors associated significantly with somatic cell count in bulk tank milk $(\times 1000 / \mathrm{ml}$ of milk $)$

\begin{tabular}{|c|c|c|c|}
\hline Factor & & Number & $\mathrm{LSM}^{1}$ \\
\hline Use of mechanical ventilation in the cowshed & $\begin{array}{l}\text { no } \\
\text { yes }\end{array}$ & $\begin{array}{r}188 \\
17\end{array}$ & $\begin{array}{l}207 \mathrm{~A} \\
153 \mathrm{~B}\end{array}$ \\
\hline Frequency of stall disinfection for cows & $\begin{array}{l}\text { no } \\
\text { once a year } \\
2-4 \text { times a year }\end{array}$ & $\begin{array}{l}33 \\
95 \\
77\end{array}$ & $\begin{array}{l}222 \mathrm{~A} \\
160 \mathrm{~B} \\
160 \mathrm{~B}\end{array}$ \\
\hline $\begin{array}{l}\text { Frequency of the milking equipment inspection by } \\
\text { a specialized service }\end{array}$ & $\begin{array}{l}\text { once a year } \\
\text { twice a year }\end{array}$ & $\begin{array}{r}186 \\
19\end{array}$ & $\begin{array}{l}243 \mathrm{~A} \\
131 \mathrm{~B}\end{array}$ \\
\hline Pre-milking manual udder massage & $\begin{array}{l}\text { no } \\
\text { yes }\end{array}$ & $\begin{array}{r}64 \\
141\end{array}$ & $\begin{array}{l}191 \mathrm{~A} \\
164 \mathrm{~B}\end{array}$ \\
\hline Length of dry period & $\begin{array}{l}2-5 \text { weeks } \\
6-8 \text { weeks }\end{array}$ & $\begin{array}{r}31 \\
174\end{array}$ & $\begin{array}{l}205 \mathrm{~B} \\
165 \mathrm{~A}\end{array}$ \\
\hline $\begin{array}{l}\text { Average amount of concentrates used per cow } \\
\text { during lactation }\end{array}$ & $\begin{array}{l}\leq 3 \mathrm{~kg} / \text { day } \\
>3 \mathrm{~kg} / \text { day }\end{array}$ & $\begin{array}{r}70 \\
135\end{array}$ & $\begin{array}{l}197 \mathrm{~A} \\
161 \mathrm{~B}\end{array}$ \\
\hline Dry roughages used in cow feeding & $\begin{array}{l}\text { straw } \\
\text { meadow hay } \\
\text { straw and meadow hay }\end{array}$ & $\begin{array}{r}13 \\
51 \\
141\end{array}$ & $\begin{array}{l}248 \mathrm{~A} \\
158 \mathrm{Ba} \\
143 \mathrm{Bb}\end{array}$ \\
\hline $\begin{array}{l}\text { Use of vitamin } \mathrm{E} \text { additive in the feed ration for } \\
\text { cows }\end{array}$ & $\begin{array}{l}\text { no } \\
\text { yes }\end{array}$ & $\begin{array}{r}41 \\
164\end{array}$ & $\begin{array}{l}191 \mathrm{a} \\
164 \mathrm{~b}\end{array}$ \\
\hline Use of $\mathrm{Cu}$ additive in the feed ration for cows & $\begin{array}{l}\text { no } \\
\text { yes }\end{array}$ & $\begin{array}{r}31 \\
174\end{array}$ & $\begin{array}{l}268 \mathrm{~A} \\
117 \mathrm{~B}\end{array}$ \\
\hline $\begin{array}{l}\text { System of reproductive heifer management be- } \\
\text { tween } 1 \text { and } 3 \text { months of age }\end{array}$ & $\begin{array}{l}\text { individual } \\
\text { group }\end{array}$ & $\begin{array}{l}102 \\
103\end{array}$ & $\begin{array}{l}153 \mathrm{~A} \\
207 \mathrm{~B}\end{array}$ \\
\hline
\end{tabular}

${ }^{1} \mathrm{LSM}$ - Least squares means. $\mathrm{P} \leq 0.05$.

A, B , a , b - LSM marked with different letters differ significantly; capital letters $-\mathrm{P} \leq 0.01$, small letters -

The factors significantly related to SPC are presented in Table 3. It may be noticed that none of these factors was significantly related to SCC, and only some analogy was found for the housing system of replacement heifers during the first month of life. Among general factors, the positive influence on microbiological quality of milk was noted for milkmen participation in specialist trainings. The method of teat 
cleaning before milking influenced the parameters analysed; their lowest levels were noted in the case of wiping with wet towel or washing with water containing a disinfectant, while the highest values were observed on farms where dry wiping was applied. Dry storage of milking apparatus between milkings (vs. plunging in water with a disinfectant) demonstrated a decreasing effect on SPC. Milk stored in tanks was characterized by considerably lower microorganism number when compared to milk stored in cans. Milk from cowsheds, where mastitis would have been the only reason of cow culling was characterized by better microbiological quality than milk from cowsheds which did not apply such a strategy. Also supplements of vitamin A and zinc influenced SPC by decreasing the level of this parameter. Besides that, the lowering influence on SPC was noted in the case of lack of application of milk from mastitic cows in calf feeding and individual housing of replacement heifers during the first month of their life.

Table 3. Factors associated significantly with standard plate count in bulk tank milk $(\times 1000 / \mathrm{ml}$ of milk $)$

\begin{tabular}{|c|c|c|c|}
\hline \multicolumn{2}{|l|}{ Factor } & \multirow{2}{*}{$\begin{array}{c}\text { Number } \\
\text { of farms }\end{array}$} & \multirow{2}{*}{$\begin{array}{l}\mathrm{LSM}^{1} \\
42 \mathrm{~A} \\
37 \mathrm{~B}\end{array}$} \\
\hline $\begin{array}{l}\text { Participation of the milkman } / \text { milkmen } \\
\text { in milking courses }\end{array}$ & $\begin{array}{l}\text { no } \\
\text { yes }\end{array}$ & & \\
\hline Pre-milking teats cleaning & $\begin{array}{l}\text { dry towel } \\
\text { wet towel } \\
\text { washing, pure water } \\
\text { washing, water containing } \\
\text { a disinfectant }\end{array}$ & $\begin{array}{l}46 \\
27 \\
99\end{array}$ & $\begin{array}{l}44 \mathrm{Aa} \\
37 \mathrm{Ba} \\
40 \mathrm{~b} \\
37 \mathrm{Ba}\end{array}$ \\
\hline Storage of clusters between milkings & $\begin{array}{l}\text { immersing in water containing } \\
\text { a disinfectant } \\
\text { dry }\end{array}$ & $\begin{array}{r}46 \\
159\end{array}$ & $\begin{array}{l}45 \mathrm{~A} \\
35 \mathrm{~B}\end{array}$ \\
\hline Equipment for milk cooling & $\begin{array}{l}\operatorname{tank} \\
\text { milk-can }\end{array}$ & $\begin{array}{r}194 \\
11\end{array}$ & $\begin{array}{l}33 \mathrm{~A} \\
47 \mathrm{~B}\end{array}$ \\
\hline $\begin{array}{l}\text { Udder diseases can be a separate reason } \\
\text { for cow culling }\end{array}$ & $\begin{array}{l}\text { no } \\
\text { yes }\end{array}$ & $\begin{array}{r}137 \\
68\end{array}$ & $\begin{array}{l}42 \mathrm{~A} \\
37 \mathrm{~B}\end{array}$ \\
\hline $\begin{array}{l}\text { Use of vitamin A additive in the feed } \\
\text { ration for cows }\end{array}$ & $\begin{array}{l}\text { no } \\
\text { yes }\end{array}$ & $\begin{array}{r}35 \\
170\end{array}$ & $\begin{array}{l}48 \mathrm{~A} \\
33 \mathrm{~B}\end{array}$ \\
\hline $\begin{array}{l}\text { Use of } \mathrm{Zn} \text { additive in the feed ration } \\
\text { for cows }\end{array}$ & $\begin{array}{l}\text { no } \\
\text { yes }\end{array}$ & $\begin{array}{r}31 \\
174\end{array}$ & $\begin{array}{l}60 \mathrm{~A} \\
26 \mathrm{~B}\end{array}$ \\
\hline $\begin{array}{l}\text { Milk from the mastitic cows is fed to } \\
\text { young female calves }\end{array}$ & $\begin{array}{l}\text { no } \\
\text { yes }\end{array}$ & $\begin{array}{r}91 \\
114\end{array}$ & $\begin{array}{l}37 \mathrm{~A} \\
42 \mathrm{~B}\end{array}$ \\
\hline $\begin{array}{l}\text { System of reproductive heifer } \\
\text { management in the first month of life }\end{array}$ & $\begin{array}{l}\text { individual } \\
\text { group }\end{array}$ & $\begin{array}{r}141 \\
64\end{array}$ & $\begin{array}{l}37 \mathrm{~A} \\
41 \mathrm{~B}\end{array}$ \\
\hline
\end{tabular}

${ }^{1} \mathrm{LSM}$ - Least squares means.

A, B, a , b - LSM marked with different letters differ significantly; capital letters $-\mathrm{P} \leq 0.01$, small letters $\mathrm{P} \leq 0.05$. 


\section{Discussion}

Mean number of cows per farm was considerably higher when compared to the national mean for individual farms, which despite the constant increase in animal concentration still fluctuated at this time around several cows (Jarka, 2007). Taking into consideration the means for SCC and SPC, it should be emphasized that the milk produced in the analysed herds more than fulfilled the requirement for extra class milk. In turn, very low coefficient of determination characterizing statistical dependence of both parameters confirms that they should be taken into account at the same time while assessing the hygienic quality of milk. Low statistical relationship between SCC and SPC is also confirmed by the fact that they were significantly connected with quite different factors, taken into consideration in the study.

Unlike the results of the present study, other works conducted in Poland demonstrated a significant influence of herd size and month on both SCC and SPC (Borkowska et al., 2001; Gardzina et al., 2002; Skrzypek et al. 2004). The lack of a relationship between herd size and SCC and SPC observed in this study may be explained by the fact that the analysed farms were much more equal in terms of cow number than in the studies of the authors quoted. In turn, the lack of the relationship between both parameters and season of the year proves, according to Wroński et al. (2008) and Dufour et al. (2011), very good prevention of udder health and proper milk handling after milking.

The results of numerous studies on organizational and technological conditions of SCC level (or udder health status) confirm an influence of factors identified in the present study. The decreasing influence of mechanical ventilation on SCC was also noted by Skrzypek (2002), who attributed this to a higher level of general hygiene of animals in cowsheds equipped with that system. It may be added that in cowsheds with forced air circulation, also higher attenuation of the effects of heat stress was noted when compared to cowsheds with gravitational ventilation. The significant relationship between heat stress and SCC was also observed, among others, by Malinowski (2001). Taking into consideration the frequency of cow stall cleaning and inspection of milking equipment efficiency, other authors also noted that these factors are connected in direct proportion to cytological quality of milk (Barkema et al., 1998; Skrzypek, 2002; Dufour et al., 2011).

The next two factors connected to SCC, i.e. manual massage of the udder before milking and length of the dry period, have in recent years been the subject of revision by a certain group of researchers and practitioners. They prompt to simplification of pre-milking procedures done manually and to shortening of dry period length below the traditional 6-8 weeks or even its elimination. Our results negate this approach and confirm the range of literature data from recent years. Taking into consideration pre-milking procedures, Skrzypek et al. (2004), Rodrigues et al. (2005) and Sandrucci et al. (2007) also noticed that their full completion favourably influences udder health status, and moreover decreases total time of animal service during milking and increases milk yield. Skrzypek et al. (2004), Pytlewski et al. (2009) and Węglarzy (2010) observed in turn, that dry period shortening below tra- 
ditionally accepted standards significantly increases SCC and decreases milk yield in a subsequent lactation.

As much as four nutritional factors demonstrated a significant relationship with SCC in the present study. Also Kamieniecki et al. (2004) and O'Rourke (2009) reveal a decreasing influence of increased supply of concentrates and the associated increase in the concentration of energy from non-structural carbohydrates in a feeding ration on SCC. According to O'Rourke (2009), appropriate concentration of dietary energy is especially important in the first 2-3 months of lactation, when high-yielding cows usually experience the negative energy balance. For that reason, decreased mastitis resistance is observed at this time, manifesting in considerably decreased immunological activity and polymorphonuclear neutrophil and macrophage motility. The same mechanism should be responsible for the highest level of SCC on farms where straw was the only roughage, because such a feeding system was certainly connected to frequent energy deficiencies. In turn, significantly lower SCC level in herds where straw and hay were concurrently used as roughages, when compared to herds where only hay was used, should be explained by the fact that some amount of straw in a ration for cows is required due to its favourable influence on physical structure of the feed consumed and fermentation processes in the rumen. Barkema et al. (1998) noticed that total withdrawal of straw from a ration increased SCC in milk of cows. Among nutritional factors, the application of vitamin $\mathrm{E}$ and $\mathrm{Cu}$ supplements demonstrated a significant relationship with SCC. Both components are important antioxidants which, by neutralizing free radicals, protect the immune system and improve its function (O'Rourke, 2009).

In addition, a decreasing effect on SCC was noted with individual housing of replacement heifers at 2 and 3 months of life. A similar relationship was reported by Skrzypek (2002) who attributes this to inter-suckling of animals maintained in a group system. In such a situation, permanent infections or increased susceptibility of an udder to infections occur at a very early age.

Unlike SCC, some information concerning the influence of only some organizational and technological factors, which were demonstrated in the present study, on SPC may be found in the literature. Kamieniecki et al. (2004), Wroński et al. (2008) and Elmoslemony et al. (2010) demonstrated a similar influence of teat cleaning before milking, noticing an unequivocally favourable effect of disinfectant used. Borkowska et al. (2001) and Gardzina et al. (2002) also demonstrated considerably higher microbiological quality of milk cooled in tanks when compared to cans. Besides that, Kamieniecki et al. (2004) noted a very positive influence of vitamin A addition to cow rations on microbiological quality of milk, attributing that to an indirect influence of better udder health status, while Kurek (1996) revealed that zinc is very easily transferred to milk and positively influences its bacteriostatic effect.

Taking into consideration other factors significantly associated with SPC, some analogous data concerning the effect of these factors on SCC may be found in the literature. Rodrigues et al. (2005) demonstrated a very positive influence of staff training level on SCC and udder health status. The same authors and Dufour et al. (2011) reveal the strong relationship between cow culling for mastitis and SCC level. Moreover, Barkema et al. (1998) noted that reproductive heifers fed with milk of 
mastitic cows are characterized by higher SCC level in milk during the productive period. In turn, as mentioned above, the individual system of reproductive heifer management at the very early age prevents inter-suckling and as a consequence results in lower SCC values in milk in the productive period of life.

In conclusion, this study demonstrated that milk produced on the analysed farms was characterized by high hygienic quality, as assessed on the basis of somatic cells and microorganisms content. It was observed that this quality may be even increased by modification and optimization of the following elements of herd management: the level of specialist knowledge in a direct animal care staff, quality of general zoohygienic conditions in cowsheds, udder preparation for milking, specialist analyses of milking equipment efficiency and its hygiene between milkings, length of dry period, strategy of culling cows suffering from mastitis, feeding of cows with concentrates and dry roughages, and also prevention of feeding of replacement heifers in the milk feeding period and their management system in the first months of life. Taking into consideration the literature information, it was proved for the first time in the present study that the following four factors have a significant influence on SPC: staff training on specialist courses, milking equipment storage between milkings, cow culling due to mastitis, and replacement heifers management system during the first month of life.

\section{References}

B arkema H.W., Schukken Y.H., Lam T.J.G.M., Beiboer M.L., Benedictus G., B rand A. (1998). Management practices associated with low, medium, and high somatic cell counts in bulk milk. J. Dairy Sci., 81: 1917-1927.

B ork ow ska D., Ja nu ś E., Ró ż y cka G. (2001). Analysis of the influence of selected factors on the properties of industrial milk, produced in individual farms (in Polish, English abstract). Zesz. Nauk. Prz. Hod., 59: 79-87.

Dufour S., Fréchette A., Barkema H.W., Mussel1 A., Scholl D.T. (2011). Invited review: Effect of udder health management practices on herd somatic cell count. J. Dairy Sci., 94: $563-579$.

E $1 \mathrm{~m}$ o s $1 \mathrm{e}$ m a n y A.M., K e e fe G.P., D o ho o I.R., W ich te 1 J.J., S try hn H., D ing we 11 R.T. (2010). The association between bulk tank milk analysis for raw milk quality and on-farm management practices. Prev. Vet. Med., 95: 32-40.

Gardzina E., Węg larz A., Feleńczak A., Ormian M., Makulska J. (2002). Microbiological quality of milk in critical points of milking and storage (in Polish, English abstract). Zesz. Nauk. Prz. Hod., 62: 97-106.

J a r k a S. (2007). Analysis of factors affecting the efficiency of dairy farms (in Polish, English abstract). Acta Sci. Pol., Oeconomia, 6: 13-18.

Kamieniecki H., Wój cik J., Kwiatek A., Skrzypek R. (2004). Factors affecting the hygienic quality of bulk tank milk (in Polish, English abstract). Med. Weter., 60: 323-326.

Kurek C. (1996). World Mastitis Congress in Tel Aviv (in Polish, English abstract). Med. Weter., 52: 32-34.

Ma 1 i n ow sk i E. (2001). Somatic cells in milk. (in Polish, English abstract). Med. Weter., 57: 13-17.

O ' R o u rke D. (2009). Nutrition and udder health in dairy cows: A review. Irish Vet. J., 62, Supp., $15-20$.

Ptak E., Jagusiak W., Żarnecki A., Otwinowska-Mindur A. (2011). Heritabilities and genetic correlations of lactational and daily somatic cell score with conformation traits in Polish Holstein cattle. Czech J. Anim. Sci., 6: 205-212. 
Pytlew ski J., A ntkowiak I., Skrzy pek R., Kę s y K. (2009). The effect of dry period length on milk performance traits of Black-and-White Polish Holstein-Friesian and Jersey cows. Ann. Anim. Sci., 9: 341-353.

Pytlewski J., Antkowiak I., Staniek M., Skrzypek R. (2010). Intensity and causes of culling in Polish Black-and-White Holstein-Friesian cows. Ann. Anim. Sci., 10: 477-487.

Rodrigues A.C.O., Caraviello D.Z., Ruegg P.L. (2005). Management of Wisconsin dairy herds enrolled in milk quality teams. J. Dairy Sci., 88: 2660-2671.

S a ndruc ci A., T a m bu rin i A., B a va L., Z u c a li M. (2007). Factors affecting milk flow traits in dairy cows: Results of a field study. J. Dairy Sci., 90: 1159-1167.

SAS ${ }^{\circledR}$ User's Guide (1996). Statistics. Version 5 Edition. SAS Inst., Cary, NC.

$\mathrm{S}$ k r z y p e k R. (2002). Somatic cell count in bulk tank milk in relation to management and technological factors (in Polish, English abstract). Med. Weter., 58: 632-635.

S krzypek R., W ój tow s ki J., F a h r R.-D. (2004). Factors affecting somatic cell count in cow bulk tank milk - a case study from Poland. J. Vet. Med., A, 51: 127-131.

S krzy pek R., Szukalski L. (2006). Performance of Black-and-White cows imported from the Netherlands and Germany compared to cows bred in Poland (in Polish, English abstract). Med. Weter., 62: 197-200.

W ę g l a r z y K. (2010). Lactation productivity of dairy cows as affected by the length of preceding dry period. Anim. Sci. Pap. Rep., 27: 301-310.

Wrón s k i M., J a r m u ż W., S k r z y pe k R. (2008). Interactions among pre-milking and post-milking procedures used in cows for protecting udder health (in Polish, English abstract). Med. Weter., 64: 327-331.

Accepted for printing 9 II 2012

\section{JAROSŁAW PYTLEWSKI, IRENEUSZ ANTKOWIAK, MACIEJ ADAMSKI, JOSEF KUČERA, RYSZARD SKRZYPEK}

\section{Czynniki związane z jakością higieniczną mleka zbiorczego produkowanego w centralnej Polsce}

\section{STRESZCZENIE}

Celem badań była analiza czynników organizacyjnych i technologicznych wpływających na liczbę komórek somatycznych (SCC) i drobnoustrojów (SPC) w mleku zbiorczym, produkowanym na terenie województwa łódzkiego. Badania przeprowadzono na podstawie ankiety wykonanej bezpośrednio w 205 gospodarstwach rodzinnych, w których utrzymywano krowy rasy polskiej holsztyńsko-fryzyjskiej odmiany czarno-białej. Dane opracowano statystycznie za pomocą wieloczynnikowej analizy wariancji. Następujące czynniki obniżały SCC w mleku: stosowanie wentylacji mechanicznej i dezynfekcji stanowisk w pomieszczeniach dla krów, częste sprawdzanie sprawności sprzętu udojowego przez wyspecjalizowany serwis (2 razy vs. 1 raz/rok), stosowanie ręcznego masażu przedudojowego wymienia, okres zasuszenia o standardowej długości 6-8 tygodni (vs. 2-5 tygodni), stosowanie pasz treściwych w ilości co najmniej $3 \mathrm{~kg}$ dziennie/krowę, stosowanie spośród pasz objętościowych suchych siana łąkowego i słomy lub tylko siana w żywieniu krów (vs. sama słoma), stosowanie dodatku witaminy E i Cu do dawki pokarmowej dla krów oraz indywidualne utrzymywanie jałówek reprodukcyjnych między 1. a 3. miesiącem życia (vs. system grupowy). Z kolei SPC było obniżone przez następujące czynniki: uczestniczenie dojarzy w specjalistycznych kursach, czyszczenie strzyków przed dojem za pomocą mokrego ręcznika lub mycia wodą zawierającą środek dezynfekcyjny, przechowywanie sprzętu udojowego między dojami ,na sucho”, brakowanie krów z powodu mastitis, stosowanie dodatków witaminy A i Zn, niestosowanie w żywieniu cieląt mleka od krów chorych na mastitis oraz indywidualny system utrzymania jałówek reprodukcyjnych w pierwszym miesiącu życia. 